UDC 378.147:811.111

Inna S. Zaiarna

$\mathrm{PhD}$ of Pedagogical Sciences, Foreign Languages Department of the Faculty of Law, a lecturer

Taras Shevchenko National University of Kyiv, Kyiv, Ukraine

ORCID ID 0000-0002-9464-096X

izaiarna@gmail.com

\title{
THE MODEL FOR E-TEACHING ENGLISH REASONING WRITING TO LAW STUDENTS BASED ON LMS MOODLE
}

\begin{abstract}
The article deals with theoretical substantiation and practical elaboration of the model for e-teaching English reasoning writing to law students based on LMS Moodle. The author analyses recent studies and publications on e-teaching English as a second language and specifics of LMS Moodle as a virtual learning environment. Special attention is paid to the description of the didactic model. Thus, the author gives a definition for the concept of 'the model for e-teaching English reasoning writing to law students based on LMS Moodle' and examines its main elements. The article describes the aims of teaching English reasoning writing, learning outcomes, the agents and the object of the educational process, their interaction, the content of learning, and forms of assessment. Based on the theoretical research relating to legal discourse as well as on the results of the survey conducted among legal practitioners, the author indicates the genres of English reasoning writing which are supposed to be effective for acquiring reasoning abilities. In addition, such methodological aspects of e-teaching English reasoning writing to law students as teaching approaches, principles and methods are highlighted. The author suggests four stages of e-teaching English reasoning writing to prospective lawyers considering specifics of both legal writing and virtual learning environment. The author also introduces a set of criteria to evaluate the outcomes of the learning process and to assess students' individual progress. Moreover, the application of LMS Moodle's administrative, training and communicative tools for teaching English reasoning writing to law students is under the author's consideration. The second part of the present research addresses the pilot testing and evaluation of the model for e-teaching English reasoning writing to law students based on LMS Moodle. Thus, the article shows the results of the pre-and post-pilot teaching, as well as their interpretation. At the end of the paper corresponding conclusions and prospects for further research are stipulated.
\end{abstract}

Keywords: a didactic model; English reasoning writing; e-teaching; law students; LMS Moodle.

\section{INTRODUCTION}

Statement of the problem. Nowadays the ability to make judgments reasonably in written English is crucial for any legal professional. It is generally recognized that such skills as proving your own opinions as well as disposing of the adversary's arguments are fundamental ones in the field of law. In conditions of growing unification and harmonization of Ukrainian legislation, a modern lawyer continually cooperates with overseas companies and organizations, drafts international agreements, corresponds with clients and colleagues from different jurisdictions, provides legal representation to their clients in international courts and commercial arbitrations.

At the same time, global integration processes and rapid development of information technologies influence not only the education content in law schools, but the way it is delivered to the students. This sets new objectives for the theory and methodology of teaching English for specific purposes in general and legal English in particular. From our perspective, the innovative technologies capable of facilitating successful acquisition of knowledge, skills and abilities in English reasoning writing used in legal discourse are the technologies of electronic teaching and learning. As mentioned in Yu. Tryus et al, they make teaching more attractive, democratic and convenient for students, since they encourage them to self-study 
and life-long learning [1, p. 6]. One of the information technologies which meets the abovementioned requirements is MOODLE - modular object-oriented dynamic learning environment, which is a free and open-source learning management system (LMS). Centralization, safety, ability to observe the educational process within the system, to compare and contract statistic data showing students' attainment automatically as well as to store them for an extended period of time are just a few advantages which LMS Moodle creates for successful e-teaching English reasoning writing to prospective lawyers.

Following the discussion above, it seems relevant to elaborate a didactic model for eteaching English reasoning writing to law students based on LMS Moodle, the one which is adapted to systematize all key elements of educational process considering specifics of both the teaching content of English reasoning writing used in legal discourse and the form of computer-mediated learning.

The analysis of recent studies and publications. Theoretical and methodological aspects of using LMS Moodle for distance teaching and learning have been studied by V.Yu. Bykov, I.V. Herasymenko, K.R. Kolos, V.M. Kukharenko, Ye.M. SmyrnovaTrybulska, O.M. Spirin, Yu.V. Tryus and others. Scientific research covers such topics as specifics of using LMS Moodle for organizing electronic teaching and learning in higher educational establishments [2], [3], the structure of e-course based on LMS Moodle [4], technical tools for creating tests, the organization of the computer-assisted control and the assessment of students' attainment [5], methods for ensuring on-line safety in educational process [6], development of Moodle-oriented didactic model for distance education [7], recommendations for the development of distance courses based on LMS Moodle and their practical implementation in teaching [1].

In light of our research, scientific works on specifics of using LMS Moodle for teaching foreign languages seem to be of particular interest. Thus, V.P. Svyrydiuk for the first time has developed an e-course for teaching essay writing in the German language based on LMS Moodle [8], N. V. Maier has provided a theoretical explanation on using LMS Moodle for self-study of French business writing and developed a new methodology suggesting electronic case application [9], O.S. Beskorsa examines specific features of LMS Moodle for organizing blended learning of German practical phonetics [10], K.V. Rudnitska and V.V. Drozdova in their recent study analyze the issue of organizing self-study of English for specific purposes by means of LMS Moodle [11], A.Yu. Yurzhenko describes an e-course based on LMS Moodle for teaching English to prospective maritime industry workers [12], foreign scholars, inter alia, Ch.-H. Lin [13], W.H. Rice [14], W.S. Wu [15] explore the peculiarities of distance course designing for teaching English as a second language based on LMS Moodle.

Despite comprehensive attention of scientific community to distance learning based on LMS Moodle and significant results in this field, methodology of e-teaching English reasoning writing to law students based on LMS Moodle has not been studied yet and requires thorough research.

The purpose of this article is to present a didactic model for e-teaching English reasoning writing to law students based on LMS Moodle and the results of its implementation in the educational process.

\section{RESEARCH METHODS}

During the study a number of methods have been used, namely: theoretical methods critical analysis of scientific literature on teaching English for specific purposes, psychology, psycholinguistics, distance learning and teaching; simulation method has been used for substantiation and development of the model for teaching English reasoning writing to law students based on LMS Moodle; empirical methods such as surveys and interviews have been 
used in order to determine the most effective genres for teaching English reasoning writing in the field of law; pilot teaching has been conducted for the evaluation of the developed model; statistic methods (Mann-Whitney U test and G-criterion) have been applied for processing and analysis of pilot teaching results.

\section{FINDINGS}

\subsection{The description of the model for e-teaching English reasoning writing to law students based on LMS Moodle}

For this particular research the model for e-teaching English reasoning writing to law students based on LMS Moodle is defined as a structural and internally organized set of interrelated elements which create a holistic complex and make it possible to simulate and improve the educational process aimed at developing law students' abilities in English reasoning writing by means of LMS Moodle. Our model is based on the study of the didactic nature of the English language teaching system, didactic and psychological features of eteaching and learning, technical characteristics of LMS Moodle, particularities of educational process addressing English reasoning writing, specifics of law students training. While developing the model for e-teaching English reasoning writing to law students based on LMS Moodle, we have taken into consideration the latest requirements to the level of English for legal professionals, drawing on the prominent foreign and domestic scholars' experience in the field of e-teaching in higher educational establishments. Thus, the key elements of our model are learning aims and outcomes, agents and the object of educational process, the content of learning, methods and forms of teaching, interaction, and forms of assessment of students' individual progress.

Following the above mentioned, let us consider thoroughly the structure of the model for e-teaching English reasoning writing to law students based on LMS Moodle, presented in Figure 1.

The model is implemented within academic discipline "A Foreign Language (English)". The agents of the educational process are the first-year law students, while the object of teaching is English reasoning writing used in the field of law.

The aim of teaching English reasoning writing to prospective lawyers is to develop students' skills and abilities in producing legal reasoning written texts independently (by receiving all the necessary information but without using any supportive materials) according to the set criteria and genre samples. To determine the most effective genres of English reasoning writing some significant steps have been taken. Firstly, we have studied relevant scientific works in the field of legal discourse in order to make a list of English reasoning written genres. Secondly, a survey among legal professionals has been conducted to specify the most typical and frequently used ones in domestic legal practice. As a result of steps taken we have defined the most effective genres of English reasoning writing. They are a letter of advice, a letter before action, a reply to a letter before action, a memorandum and a legal complaint.

Learning outcomes. At the end of distance learning devoted to English reasoning writing, law students by acquiring text-productive abilities will be able to produce English reasoning written texts independently without using any supportive materials in such genres within legal discourse as a letter of advice, a letter before action, a reply to a letter before action, a memorandum, a legal complaint; by acquiring lexical and grammatical skills in producing English reasoning writing they will be able to recognize compositional and genrestylistic features of the defined genres. Students will be able to formulate legal issues, analyze relevant facts, define potential risks and the ways to resolve them, to communicate in written 
form meaningfully at a level not lower than B2. Students will be able to analyze other students' English reasoning writing, recognize reasoning tactics and distinctive language material with the purpose to use them in their own texts in future.

The content of learning. Teaching English reasoning writing to law students is characterized by topics and communicative situations typical of legal writing. Language and speech learning materials essential for prospective lawyers while producing English reasoning writing include lexical units, grammatical structures, linking words and phrases, background vocabulary, cliché, forms of speech etiquette, genre and compositional characteristics of the texts, cultural component of reasoning semantics. The content of teaching English reasoning writing includes the knowledge of legal component, functional subtypes of argumentative speech, tactics and linguistic means for their effective implementation, compositional features of various genres of English reasoning writing and their linguistic and sociocultural characteristics; grammatical and lexical skills; abilities to analyze the text from the point of view of the presence of reasoning tactics in it, to define and use the language intrinsic to English reasoning writing, as well as compositional and genre-stylistic features of texts, abilities to select, plan and organize information in writing, to produce complete written texts, arguing personal points of view with the help of the appropriate linguistic means, abilities to find the most typical for the legal community means and ways of achieving communicative goals as well as the implementation of communicative strategies.

Aim: to develop students' skills and abilities in producing legal reasoning written texts according to the set criteria and genre samples.

\begin{tabular}{|c|c|c|c|c|c|c|}
\hline 1 & \multicolumn{2}{|l|}{$\downarrow$} & $\downarrow$ & & $\downarrow$ & $\downarrow$ \\
\hline $\begin{array}{l}\text { ERW genres: } \\
\text { a letter of advice } \\
\text { a letter before } \\
\text { action } \\
\text { a reply to a letter } \\
\text { before action } \\
\text { a memorandum } \\
\text { a legal complaint }\end{array}$ & \multicolumn{2}{|c|}{$\begin{array}{l}\text { The content of learning: } \\
\text {-topics and } \\
\text { communicative situation } \\
\text { relating to the existing } \\
\text { legal practice; } \\
\text {-language and speech } \\
\text { materials; } \\
\text {-knowledge, skills, } \\
\text { abilities. }\end{array}$} & $\begin{array}{l}\text { Approaches: } \\
\text {-Constructive; } \\
\text {-Competence- } \\
\text { based; } \\
\text {-Genre-based. }\end{array}$ & \multicolumn{2}{|c|}{$\begin{array}{l}\text { Principles: } \\
\text {-didactic; } \\
\text {-psychological; } \\
\text {-methodological }\end{array}$} & $\begin{array}{l}\text { Methods: } \\
\text {-case- } \\
\text { method; } \\
\text {-Socratic } \\
\text { method. }\end{array}$ \\
\hline 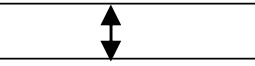 & I & & I & & 主 & I \\
\hline \multicolumn{7}{|c|}{ Virtual learning environment: LMS Moodle } \\
\hline 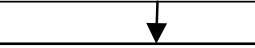 & \multicolumn{3}{|c|}{$\downarrow$} & \multicolumn{3}{|c|}{$\downarrow$} \\
\hline Module 1 & \multicolumn{3}{|c|}{ Module 2} & \multicolumn{3}{|c|}{ Module n } \\
\hline Stage 1 & \multicolumn{3}{|c|}{ Stage 1} & \multicolumn{3}{|c|}{ Stage 1} \\
\hline Stage 2 & \multicolumn{3}{|c|}{ Stage 2} & \multicolumn{3}{|c|}{ Stage 2} \\
\hline Stage 3 & \multicolumn{3}{|c|}{ Stage 3} & & \multicolumn{2}{|c|}{ Stage 3} \\
\hline Stage 4 & \multicolumn{3}{|c|}{ Stage 4} & & \multicolumn{2}{|c|}{ Stage 4} \\
\hline$\downarrow$ & \multicolumn{3}{|c|}{$\downarrow$} & & \multicolumn{2}{|c|}{$\downarrow$} \\
\hline \multicolumn{7}{|c|}{$\begin{array}{l}\text { Learning outcome: Students will be able to produce legal English reasoning written texts in such } \\
\text { genres as a letter of advice, a letter before action, a reply to a letter before action, a memorandum, a } \\
\text { legal complaint; and do it independently without using any supportive materials by operating reasoning } \\
\text { tactics and relevant language material. }\end{array}$} \\
\hline \multicolumn{7}{|c|}{ The Learning Module Structure } \\
\hline Stages & $\begin{array}{l}\text { Number } \\
\text { of hours }\end{array}$ & $\begin{array}{l}\text { The obj } \\
\text { teachi }\end{array}$ & $\begin{array}{l}\text { Technical too } \\
\text { Moodle ser }\end{array}$ & & $\begin{array}{c}\text { Interac- } \\
\text { tion }\end{array}$ & $\begin{array}{l}\text { Forms of } \\
\text { assessment }\end{array}$ \\
\hline
\end{tabular}




\begin{tabular}{|c|c|c|c|c|c|}
\hline Stage 1 (Preparatory stage) & 2 & $\begin{array}{l}\text { Speech } \\
\text { skills }\end{array}$ & $\begin{array}{l}\text { Lesson, Glossary, } \\
\text { Assignment, } \\
\text { Test, } \\
\text { Chat, } \\
\text { Forum, } \\
\text { Messaging }\end{array}$ & $\begin{array}{l}\text { SC } \\
\text { SI } \\
\text { ST } \\
\text { SS }\end{array}$ & $\begin{array}{l}\text { Formative } \\
\text { assessment }\end{array}$ \\
\hline Learning outcome & \multicolumn{5}{|c|}{$\begin{array}{l}\text { Students will know lexical units and grammatical structures typical for } \\
\text { English reasoning writing in the field of law and be able to apply the } \\
\text { acquired knowledge while writing legal texts of specified genres. }\end{array}$} \\
\hline Stage 2 (Analytical stage) & 3 & $\begin{array}{l}\text { the } \\
\text { knowledge } \\
\text { of structure } \\
\text { and } \\
\text { compositio } \\
\text { n; } \\
\text { language } \\
\text { skills; } \\
\text { analytical } \\
\text { abilities. }\end{array}$ & $\begin{array}{l}\text { Lesson, } \\
\text { Assignment, } \\
\text { Test, } \\
\text { Chat, } \\
\text { Forum, } \\
\text { Wiki }\end{array}$ & $\begin{array}{l}\text { SC } \\
\text { SI } \\
\text { ST } \\
\text { SS }\end{array}$ & $\begin{array}{l}\text { Formative } \\
\text { assessment }\end{array}$ \\
\hline Learning outcome & \multicolumn{5}{|c|}{$\begin{array}{l}\text { Students will know structural components of specified genres of English } \\
\text { reasoning writing, as well as their typical lexical units and grammatical } \\
\text { structures. }\end{array}$} \\
\hline Stage 3 (Practice stage) & 3 & $\begin{array}{l}\text { Abilities in } \\
\text { reasoning }\end{array}$ & $\begin{array}{l}\text { Lesson, } \\
\text { Assignment, } \\
\text { Test, } \\
\text { Chat, } \\
\text { Forum }\end{array}$ & $\begin{array}{l}\text { SC } \\
\text { SI } \\
\text { ST } \\
\text { SS }\end{array}$ & $\begin{array}{l}\text { Formative } \\
\text { assessment }\end{array}$ \\
\hline Learning outcome & \multicolumn{5}{|c|}{$\begin{array}{l}\text { Students will know logical and linguistic structure of reasoning; will be } \\
\text { able to define a statement, arguments and a conclusion within a specified } \\
\text { communicative situation. }\end{array}$} \\
\hline $\begin{array}{l}\text { Stage } 4 \text { (Text-productive } \\
\text { stage) }\end{array}$ & 4 & $\begin{array}{l}\text { Text- } \\
\text { productive } \\
\text { abilities }\end{array}$ & $\begin{array}{l}\text { Assignment, } \\
\text { Test, } \\
\text { Chat, } \\
\text { Forum, } \\
\text { Workshop, } \\
\text { Wiki }\end{array}$ & $\begin{array}{l}\text { SC } \\
\text { SI } \\
\text { ST } \\
\text { SS }\end{array}$ & $\begin{array}{l}\text { Formative } \\
\text { assessment, } \\
\text { summative } \\
\text { assessment }\end{array}$ \\
\hline Learning outcome & \multicolumn{5}{|c|}{$\begin{array}{l}\text { Students will be able to draft a text of English reasoning writing genre } \\
\text { independently according to specified criteria and set samples. }\end{array}$} \\
\hline
\end{tabular}

Figure 1. The model for e-teaching English reasoning writing to law students based on LMS Moodle

The conducted research of methodological aspects of e-teaching English reasoning writing to law students based on LMS Moodle allows us to define the main approaches, principles and methods of e-teaching. Thus, e-teaching of English reasoning writing should be performed from the perspective of the constructivist, competency-based and genre approaches which are supposed to ensure an effective organization of learning process aimed at formation of skills and abilities in English reasoning writing in the conditions of unfamiliar learning environment which is realized through the interface of digital means of information processing by human-machine communication. The determined approaches are implemented under the following learning principles: didactic, which include proximity, conscientiousness, active participation, visibility; psychological, which include motivation, gradual formation of 
skills and abilities, individual psychological peculiarities of the student's personality, adaptive processes; and the methodological principles, which encompass the leading role of communication, authenticity of learning materials, professional orientation of learning, situationality. Key methods for e-teaching English reasoning writing to law students are thought to be case-method and the Socratic Method. They address acquiring essential reasoning skills and abilities, correspond to the abovementioned approaches and principles and are adequately implemented in virtual learning environment based on LMS Moodle.

Another aspect we believe to be significant for e-teaching English reasoning writing to law students is the organization of content implementation, which should take into account the determined approaches, principles and methods as well as the specifics of virtual learning environment. From our perspective, effective e-teaching English reasoning writing should consist of five modules each of which addresses a particular genre of English reasoning writing. We suggest that each learning module be organized in four stages: preparatory, analytical, practice and text-productive. To complete each module a student is supposed to spend from one to two hours a day during ten days. In order to provide full understanding of the process, let us consider the specifics of each stage.

The preparatory stage is aimed at developing speech skills in producing texts of a particular genre of English reasoning writing. It also focuses on preventing language and subject content difficulties. The preparatory stage lasts two academic hours, during which students are supposed to complete from four to five exercises of different types and kinds. At this stage we use pass/fail grades to assess students' performance. The number of attempts for completing a task is not limited but in order to move to the next stage all exercises of the preparatory stage should be accomplished.

The preparatory stage is followed by analytical one, which in its turn lasts three academic hours. The analytical stage is aimed at analyzing texts for defining compositional and genre-stylistic features of the genre it is devoted to. Students are supposed to accomplish from five to six exercises of different types. Similar to the previous stage, pass/fail grades are used to assess students' performance. We do not limit the number of attempts to fulfill the tasks. However, a student should get 'a pass' for each assignment to move to the third stage.

The third stage - the practice stage - concentrates on such objectives as formulating a statement, arguments and a conclusion as well as preventing logical difficulties. This stage requires the accomplishment of six to eight exercises of different types, which are assessed according to a pass/fail system. The successful completion of all tasks allows students to move to the final stage.

The text-productive stage requires four academic hours and addresses developing reasoning and text-productive abilities by students' producing their own texts of a particular genre within a legal discourse. The module is considered to be completed successfully if a student accomplishes a final assignment, which is assessed according to the set criteria: task achievement, reasoning structure, lexical resource, grammatical accuracy and style compliance. Students are given two academic hours and one attempt to fulfill a final task.

Thus, the defined staging is supposed to facilitate the effective organization of the learning process aimed at acquiring abilities in English reasoning writing, taking into account the specifics of the legal discourse and virtual learning environment. At the same time, successful implementation of e-teaching English reasoning writing greatly depends on LMS Moodle's technical tools designed to ensure electronic teaching and learning. These technical tools can be divided into three groups: communicative tools (Forum, Chat, Messaging), training tools (Lesson, Assignment, Test, Survey, Wiki, Glossary, Workshop) and administrative tools (Groups, Assessment, Report). In their combination these tools create the required technical support for e-teaching English reasoning writing. Moreover, the LMS 
Moodle's multi-functional toolkit ensures the implementation of such model elements as interaction and forms of assessment, which we are going to consider further.

For the systematic understanding of e-teaching English reasoning writing to law students the interaction of all agents of the learning process, as well as their content perception through the interface of the computer are of a particular importance. Thus, on the basis of T. Anderson and F. Elloumni's [16] findings we define such types of interaction for our model as student-student (SS), student-teacher (ST), student-content (SC), studentinterface (SI).

As for the forms of assessment, during e-teaching English reasoning writing formative and summative ones should be used. Thus, formative assessment is aimed at realizing educational and developmental functions as well as providing ongoing feedback. For our model we use a pass/fail system, grades and comments. Summative assessment, however, is used to evaluate student's learning at the end of each module and the whole course. The significant benefit of LMS Moodle that is particularly useful for formative assessment is the possibility to make unlimited number of attempts to complete the task. To improve students' learning we also use the mutual control, when students check out and evaluate each other's works, and self-control, when students analyse and correct their own texts.

To sum up, the developed model for e-teaching English reasoning writing to law students based on LMS Moodle is implemented during six weeks (60 academic hours). The model has a modular structure. Each module addresses teaching one particular genre of English reasoning writing (a letter of advice, a letter before action, a reply to a letter before action, a memorandum, a legal complaint), lasts 12 academic hours and is organized in four stages. Thus, preparatory stage needs two hours, analytical and practice stages require three hours each, text-productive stage - four academic hours. To realize the model successfully, a number of LMS Moodle's technical tools is used, as well as other specifics of virtual learning environment are taken into consideration.

To evaluate the effectiveness of the described model, the pilot testing has been conducted. Its findings and their interpretation are shown further.

\subsection{The pilot testing of the model for e-teaching English reasoning writing to law students based on the LMS Moodle}

The pilot testing of our model lasted sixty-four hours and consisted of three phases: preexperimental assessment, pilot teaching, post-experimental assessment. Fifty-two first-year students of the Faculty of Law at Taras Shevchenko National University of Kyiv participated in the model pilot-testing. To ensure credible results we formed two experimental groups (EG) equal in quantity and the level of their abilities in English reasoning writing.

The invariable conditions for both experimental groups during the pilot-testing were the groups' membership equal in the quantity of their members and the level of their abilities in English reasoning writing before the pilot testing; the aims and the learning content, the objects and criteria of assessment, pre-experimental and post-experimental tests. The variable condition of the pilot testing was the technology for distance teaching English reasoning writing. Variant A: Students of EG-1 learned reasoning strategies in writing on LMS Moodle in the conditions of managed learning provided by the means of LMS Moodle's administrative, training and communicative tools. The managed learning gives a possibility to observe and monitor the learning process and this, in turn, allows providing support in order to prevent or overcome potential difficulties. Variant B: Students of EG-2 learned reasoning strategies in writing by the means of open technologies, the technical capacity of which makes it possible to display learning material in its entirety; however, we cannot observe and monitor the learning process, which ipso facto questions the assessment results. 
To prove the effectiveness of the developed model for e-teaching English reasoning writing to law students, the results of pre- and post-experimental assessment were contrasted and compared. To ensure their validity, certain requirements were met. Firstly, pre- and postexperimental tests contain the same task: to produce one of the pieces of English reasoning writing (student's choice) based on the specified situation. Secondly, both pre- and postexperimental assessments were carried out at same time for EG-1 and EG-2 in the classrooms under teachers' observation. Thirdly, students' pieces of writing were assessed according to the same set criteria which are described above in the paper.

Table 1 provides summary data for the results of pre- and post-experimental assessment based on the defined criteria.

Table 1

The results of pre- and post-experimental assessment based on the defined criteria

\begin{tabular}{|c|c|c|c|c|}
\hline \multirow[t]{2}{*}{ № } & \multirow[t]{2}{*}{ Criteria assessment } & \multirow{2}{*}{$\begin{array}{c}\text { The } \\
\text { maximum } \\
\text { value }\end{array}$} & \multicolumn{2}{|c|}{ The average value } \\
\hline & & & EG - 1 & EG-2 \\
\hline 1. & Task achievement & 5 & $2,85>3,88$ & $2,89-8,15$ \\
\hline 2. & Reasoning structure & 5 & $2,424,12$ & $2,46 \& 81$ \\
\hline 3. & Lexical resource & 5 & $2,92>4,15$ & $2,96 \$, 62$ \\
\hline 4. & Grammatical accuracy & 5 & $3,23,3,89$ & $3,19 \$, 85$ \\
\hline 5. & Style compliance & 5 & $3,424,19$ & $3,423,92$ \\
\hline & $\begin{array}{l}\text { The average index for the ability } \\
\text { formation level }\end{array}$ & 1 & $0,5 \$ 0,81$ & $0,60 \bigotimes, 69$ \\
\hline
\end{tabular}

The comparison and analysis of the received results of the pre- and post-experimental assessment shows that the average index in both experimental groups has grown. However, only the students of EG-1 have been able to achieve the average index higher than $\mathrm{I}=0.7$. In this way the effectiveness of Variant A of our model for e-teaching English reasoning writing based on LMS Moodle has been proved. The validity of the pilot-testing results has been proved by the means of statistic methods (Mann-Whitney U test and G-criterion).

\section{CONCLUSIONS AND PROSPECTS FOR FURTHER RESEARCH}

The conducted theoretical research as well as its pilot-testing allows us to state that the developed model ensures the high efficiency of e-teaching English reasoning writing to law students. At the end of their training law students are able to produce English reasoning writing within a legal discourse independently, according to the specified criteria and set samples. The successful result is achieved under the following conditions: the organization of training is carried out on the principles of constructivist, competence and genre approaches as well as in accordance with the didactic, psychological and methodological principles we have established; the use of the Socratic method and the case-method; the organization of training on the basis of such genres of English reasoning writing as a letter-advice, a letter before action, a reply to a letter before action, a memorandum, a legal complaint; the use of LMS Moodle's administrative, training and communicative tools.

The results of the pilot testing show that LMS Moodle provides all required conditions for achieving set aims and objectives. Thus, LMS Moodle's administrative, training and communicative tools allow us to supply students with all necessary training materials displayed in various electronic formats (texts, audio- and video files, PowerPoint presentations, etc.) to maintain students' motivation for learning. Moreover, the managed 
learning environment of LMS Moodle ensures the observation and monitoring of the learning process. A tutor is able not just to provide the required correction of mistakes and the kind of support requested but also to prevent potential difficulties related to the acquisition of skills and abilities in English reasoning writing. In addition, a wide range of test types available on LMS Moodle give us an opportunity to assess students' performance at all stages of the learning process.

Another significant benefit provided by LMS Moodle which is worth emphasizing is its flexibility and adaptability to students' needs. Our students admit that they learned a lot by watching others as well as by creating and expressing with and for others (Wiki activity, forum and chat posts were highlighted). Furthermore, students are able to learn at the appropriate time provided that they meet deadlines. They can manage their time, since the whole process is structured and organized on the same site.

In light of the abovementioned we strongly believe that e-teaching of English reasoning writing based on LMS Moodle is efficient as it meets necessary requirements of the modern educational process and suits students' needs. It can easily replace classroom learning with self-learning in the part of English reason writing and significantly strengthen students' productivity.

In terms of the prospects for further research we suggest that the methodological guidelines for e-teaching English reasoning writing to law students aimed at preventing potential difficulties and considering the specifics of LMS Moodle should be developed.

\section{REFERENCES (TRANSLATED AND TRANSLITERATED)}

[1] Tryus, Yu. V. \& Herasymenko, I.V. \& Franchuk, V.M. (2012).Moodle-based electronic learning system in higher educational establishments: Training manual. Cherkasy. (in Ukrainian).

[2] Bykov, V. \& Kukharenko, V. (2008). The technology of creating a distance learning course: Training manual. Kyiv: Millennium. (in Ukrainian).

[3] Kykharenko, V. M. \& Molodykh, H.S., "The analysis of students' engagement in distance learning course",New information technologies in educational establishments of Ukraine, vol. 9, part 1, 2002. Odesa. (in Ukrainian).

[4] Herasymenko, I.V., "The course designing in the system of Moodle-based electronic learning”.Pedagogical almanac,vol. 16, 2012. Kherson. (in Ukrainian).

[5] Smyrnova-Trybulska, Ye. M. (2007). Moodle-based distance learning: training manual. Kherson: Ailant. (in Ukrainian).

[6] Spirin, O.M. \& Kovalchuk, V.M., "Methodic of the on-line safety of the senior pupils in the teaching and educational process at school", Information Technologies and Learning Tools, vol. 21, no. 1, 2011. (in Ukrainian).

[7] Kolos, K.R. (2011). LMS Moodle as a means for the development of Computer Science teachers' subject competences in the conditions of distance postgraduate education: a $\mathrm{PhD}$ thesis in Pedagogical Studies, 13.00.10. Ivan FrankoZhytomyr State University. (in Ukrainian).

[8] Svyrydiuk, V.P. (2007). Methodology of teaching German writing to part-time students of higher language education establishments based on a distance course: a summary for a $\mathrm{PhD}$ thesis in Pedagogical Studies, 13.00.02. KNLU. (in Ukrainian).

[9] Mayer, N.V. (2011). Methodology of perspective document examiners' self-study of French business writing by the means of distance technologies: a $\mathrm{PhD}$ thesis in Pedagogical Studies, 13.00.02. Kyiv. (in Ukrainian).

[10] Beskorsa, O.S. "Virtual learning environment MOODLE as a means to organize blended learning in teaching practical phonetics of German language", Information Technologies and Learning Tools, vol. 62, no. 6, 2017. (in Ukrainian).

[11] Rudnitska, K.V. \& Drozdova, V.V. "Organization of students' self-study by means of MOODLE system for foreign language learning”, Information Technologies and Learning Tools, vol. 63, no. 1, 2018. (in Ukrainian).

[12] Yurzhenko, A. Yu. "An e-course based on the LMS MOODLE to teach "maritime English for professional purpose", Information Technologies and Learning Tools, vol. 71, no. 3, 2019. (in English). 
[13] Lin, Ch.-H. "Using Moodle in a General Education English as a Second Language Program: Taiwanese College Student Experiences and Perspectives", Journal of Educational and Social Research, vol. 3, no. 3. 2013. (in English).

[14] Rice, I. \& William, H. (2006). Moodle E-Learning Course Development: a complete guide to successful learning using Moodle. Birmingham: Packet Publishing. (in English).

[15] Wu, W.-Sh. "The application of Moodle on an EFL collegiate writing environment", Journal of Education and Foreign Languages and Literature, vol. 7, 2008. (in English).

[16] Anderson, T. (2004). Theory and practice of online learning. Athabasca University. (in English).

Text of the article was accepted by Editorial Team 22.08.2019

\title{
МОДЕЛЬ ЕЛЕКТРОННОГО НАВЧАННЯ АНГЛІЙСЬКОГО АРГУМЕНТАТИВНОГО ПИСЬМА СТУДЕНТІВ-ЮРИСТІВ HA OCHOBI LMS MOODLE
}

\author{
Заярна Інна Сергіївна \\ кандидат педагогічних наук, викладач кафедри іноземних мов юридичного факультету \\ Київський національний університет імені Тараса Шевченка, м. Київ, Україна \\ ORCID ID 0000-0002-9464-096X \\ izaiarna@gmail.com
}

\begin{abstract}
Анотація. Стаття присвячена теоретичному обгрунтуванню, розробці та експериментальній перевірці моделі електронного навчання англійського аргументативного письма майбутніх юристів на основі LMS Moodle. У статті проаналізовано останні дослідження, у яких розкривається проблематика електронного навчання англійської мови як іноземної, а також вивчаються особливості LMS Moodle як віртуального навчального середовища. У роботі визначено методи та мету дослідження. Особлива увага приділена опису дидактичної моделі. Так, автор пропонує визначення поняття «Модель електронного навчання англійського аргументативного письма студентів-юристів на основі LMS Moodle» та розглядає ऑï основні елементи. У статті описано цілі навчання англійського аргументативного письма, очікуваний результат, суб єкти і об`єкт навчання, їх взаємодію, зміст навчання та форми оцінювання. Грунтуючись на теоретичних дослідженнях, присвячених юридичному дискурсу, а також враховуючи результати опитування, проведеного серед практикуючих юристів, автор виокремлює жанри англійського аргументативного письма, які $\epsilon$ ефективними для оволодіння аргументативними уміннями. Крім того, автором висвітлюються такі методичні аспекти електронного навчання англійського аргументативного письма студентів-юристів на базі LMS Moodle, як підходи, принципи i методи. Враховуючи особливості юридичного письма i віртуального навчального середовища, автор пропонує чотири етапи електронного навчання англійського аргументативного письма майбутніх юристів. Щоб оцінити результати навчального процесу, автором також визначаються необхідні критерії. Значна увага у статті також приділена особливостям застосування адміністративних, навчальних та комунікативних інструментів LMS Moodle для навчання англійського аргументативного письма студентівюристів. Друга частина даного дослідження присвячена експериментальній перевірці ефективності моделі електронного навчання англійського аргументативного письма майбутніх юристів на основі LMS Moodle. Так, у статті представлені результати перед i післяекспериментальних зрізів та їх інтерпретація. За результатами роботи зроблені відповідні висновки та сформульовані перспективи подальших наукових розвідок.
\end{abstract}

Ключові слова: дидактична модель; англійське аргументативне письмо; електронне навчання; студенти-юристи; LMS Moodle. 


\title{
МОДЕЛЬ ЭЛЕКТРОННОГО ОБУЧЕНИЯ АНГЛИЙСКОМУ АРГУМЕНТАТИВНОМУ ПИСЬМУ СТУДЕНТОВ-ЮРИСТОВ HA OCHOBE LMS MOODLE
}

\section{Заярная Инна Сергеевна}

кандидат педагогических наук, преподаватель кафедры иностранных языков юридического факультета Киевский национальный университет имени Тараса Шевченко, г. Киев, Украина

ORCID ID 0000-0002-9464-096X

izaiarna@gmail.com

\begin{abstract}
Аннотация. Статья посвящена теоретическому обоснованию, разработке и экспериментальной проверке модели электронного обучения английскому аргументативному письму будущих юристов на основе LMS Moodle. B статье проанализированы последние исследования, в которых раскрывается проблематика электронного обучения английскому языку как иностранному, а также изучаются особенности LMS Moodle как виртуальной среды обучения. В работе определены методы и цель исследования. Особое внимание уделено описанию дидактической модели. Так, автор предлагает определение понятия «Модель электронного обучения английскому аргументативному письму студентов-юристов на основе LMS Moodle» и рассматривает еe основные элементы. В статье описаны цели обучения английскому аргументативному письму, ожидаемый результат, субъекты и объект обучения, их взаимодействие, содержание обучения и формы оценки. Основываясь на теоретических исследованиях, посвященных юридическому дискурсу, а также учитывая результаты опроса, проведенного среди практикующих юристов, автор выделяет жанры английского аргументативного письма, которые являются эффективными для овладения аргументативними умениями. Более того, автором освещаются такие методические аспекты электронного обучения английскому аргументативному письму студентов-юристов на базе LMS Moodle, как подходы, принципы и методы. Учитывая особенности юридического письма и виртуальной среды обучения, автор предлагает четыре этапа электронного обучения английскому аргументативному письму будущих юристов. Для оценки результатов учебного процесса автором также определяются необходимые критерии. Значительное внимание в статье уделено особенностям применения административных, учебных и коммуникативных инструментов LMS Moodle для обучения английскому аргументативному письму студентов-юристов. Вторая часть данного исследования посвящена экспериментальной проверке эффективности модели электронного обучения английскому аргументативному письму будущих юристов на основе LMS Moodle. Так, в статье представлены результаты пред и после-экспериментальных срезов и их интерпретация. По результатам работы сделаны соответствующие выводы и сформулированы перспективы дальнейших научных исследований.
\end{abstract}

Ключевые слова: дидактическая модель; английское аргументативное письмо, электронное обучение; студенты-юристы; LMS Moodle.

\section{$(\mathrm{cc})$ BY-NC-SA}

This work is licensed under Creative Commons Attribution-NonCommercial-ShareAlike 4.0 International License. 